\title{
Global Liquidity, the Private Sector and Debt Sustainability in Sub-Saharan
} Africa

\section{Bruno Bonizzi, Christina Laskaridis and Jan Toporowski}

\begin{abstract}
This article analyses the effect of changes in international financial markets on the debt dynamics in sub-Saharan Africa in recent years. A key development is the rise of the private sector as both a lender and a borrower in African debt markets, a process that is associated with the growing integration of the region into global financial markets. The article argues that the Debt Sustainability Framework of the International Monetary Fund and World Bank has taken some steps to account for this growth of private sector, cross-border debt, but such steps still fall short of what is needed. A full appreciation of the importance of private debt implies, first, that debt sustainability in sub-Saharan Africa be understood in the context of countries' integration in global financial markets and the global liquidity cycles that characterize those markets and, second, that the interplay between private and public debt be monitored in order to provide a fuller picture of the impact of private sector debt on fiscal sustainability.
\end{abstract}

[first, unnumbered footnote]

The authors wish to thank the anonymous reviewers for their helpful feedback and Andreas Antoniades, Stephanie Blankenburg, Penelope Hawkins and Ewa Karwowski for comments on an earlier version, and UNCTAD for financing earlier research on this subject. All errors are the authors' own. 


\section{INTRODUCTION}

When the latest round of multilateral debt relief was approved in 2006, the World Bank, the African Development Bank (AfDB) and the International Monetary Fund (IMF) emerged confident that the 'dragon of unsustainable debt finally had been slain' (Leo, 2009: 1). This optimism was not seriously shaken by the 2008 financial crisis, as the World Bank argued that 'notwithstanding the severity of the shock ... the impact was less pronounced than in other regions' (World Bank, 2010: 154). Economic growth in sub-Saharan Africa remained buoyant in 2008 and 2009, supporting the World Bank's view that the region's growth potential had somewhat decoupled from advanced economies.

However, the narrative of Africa rising seems to have been replaced recently with an African debt-rising narrative (Adams, 2015). The head of the AfDB and the Managing Director of the IMF have warned of the potential of a new debt crisis (Aglionbi, 2016), while the United Nations Conference on Trade and Development (UNCTAD, 2015a) highlights the dangers of a new debt trap (see also IMF, 2018).

This article argues that the Debt Sustainability Framework (DSF), jointly developed by the World Bank and IMF to analyse debt sustainability in low-income countries, has shortcomings in terms of its ability to address these recent developments. The shortcomings can be summarized as follows: the DSF largely overlooks the importance of the private sector and the integration of that sector in sub-Saharan Africa's external debt structures. The DSF is predominantly geared towards prioritizing an analysis of growth of external debt that arises out of current accounts and trade dynamics. While current accounts dynamics can be an important concurrent factor to a debt crisis, they cannot by themselves reveal all information about debt sustainability, that is, the ability of a country's citizens to finance their debt. In conditions of emerging financial integration, financing a debt depends on a country's ability to access financial markets dominated by private and institutional investors and lenders. Notwithstanding the IMF's growing acknowledgement of the inadequacy of the DSF to account for private actors (IMF, 2016b) there is insufficient advancement at the policy level. This is despite a long history stretching back as far as the emerging market crises of the 1990s and fiscal crises brought on by external capital outflows of the private sector (UNCTAD, 2016). Although changes have been made since the 2008 financial crisis, there remains a substantial degree of continuity in the approach to debt sustainability as well as the 
conditionality policies that follow in the wake of debt problems (Gabor, 2010; Güven, 2012; Rakshit, 2009).

This study documents the growing importance of the private sector - a key factor in subSaharan Africa's emergent financial integration and in its lending and borrowing. Understanding this phenomenon is crucial to analysing the sustainability of sub-Saharan African debt. In particular, the recent deterioration in sub-Saharan African debt indicators can be better understood by examining their dependence on the global cycle that determines the liquidity of international financial markets. According to Jaime Caruana, General Manager of the Bank for International Settlements, 'global liquidity' can be defined as the 'ease of international financing in the international financial system' (BIS, 2013: 2). This depends on the actions of both private and public actors (Eickmeier et al., 2013; Landau, 2013) and in the last decade has been closely associated with the expansionary monetary policy of major advanced economies (Aizenman et al., 2014; Chen et al., 2012; Fischer, 2015; Rey, 2013; Shin, 2012, 2013). Abundant global liquidity in the post-financial crisis years has enabled sub-Saharan African countries to borrow easily and refinance their debts, while exposing them to the vulnerabilities of liquidity shrinkages and shifts in the risk appetite of global lenders (Akyüz, 2017; Bonizzi, 2017a; Fischer, 2015; Kaltenbrunner, 2010; Kaltenbrunner and Painceira, 2015, 2017). The growing importance of private actors may also have major consequences via the complex interplay between private and public debt whose interaction and conceptualization is limited in the DSF, as recognized by the latest DSF review (IMF, 2017a). Countries in sub-Saharan Africa have little control over these processes, which deserve to be examined in greater detail in terms of debt sustainability.

This article documents the growing importance of financial integration in terms of the impact on recent debt dynamics and shows that debt sustainability is highly contingent on the state of global liquidity. This does not fit with the country-based assessments of debt sustainability nor the domestic policy reforms, such as fiscal contractions, imposed to deal with 'unsustainable' debt. The article is structured as follows. The second section sets the context of the DSF and its limited capacity to capture the consequence of financial integration in assessing debt sustainability. The third section explores the importance of global liquidity for debt sustainability and the important interplay between private and public sector debt. In the fourth section, we look at the rise of private actors in sub-Saharan Africa's external debt composition; we find that it is concentrated in a small group of countries and can be understood within the context of greater financial integration. In the fifth section, we show 
how the degree of financial integration — rather than commodity reliance or previous debt relief - is the main determinant of the recent deterioration of debt sustainability in subSaharan Africa, emphasizing the key role played by global liquidity in this process. The final section concludes with some policy recommendations.

\section{DEBT SUSTAINABILITY FRAMEWORK: EVOLVING BUT NOT QUITE ENOUGH}

Debt sustainability is a heavily debated issue in the theoretical and empirical literature and yet remains hard to pin down in practice (Wyplosz, 2011). Although it remains analytically an ambiguous concept (Guzman and Heymann, 2016), the practice of assessing debt sustainability by the Bretton Woods institutions is necessarily empirical. The majority of economies in sub-Saharan Africa are classified as low-income countries and their debts are reviewed by the DSF through the joint collaboration between these low-income countries, the IMF and the World Bank. Assessments of market access countries (MACs) follow the approach specified by the IMF (2013a). ${ }^{1}$ The basic framework, introduced in 2005 and revised four times since, ${ }^{2}$ pools together two separate assessments, one on total external debt and the other on public debt. Sustainability is therefore respectively linked to the evolution of the current account and the evolution of the budget deficit, with each including sets of indicators of solvency and liquidity.

The analytical underpinnings of solvency requirements arise from the satisfaction of an inter-temporal budget constraint: 'For a government to be solvent, the PV [present value] of future primary balances must be greater than or equal to the public debt stock. For a country as a whole, the PV value of future non-interest current account balances must be greater than or equal to its external debt' (IMF, 2013b: 6). These calculations are based on a number of projections and assumptions about key economic variables, such as the rate of interest relative to the rate of economic growth, as well as the choice of time horizon and discount rate, which in the last IMF review was kept at 5 per cent for all low-income countries (IMF, 2017a). Whereas over an infinite time horizon all debts could be solvent, over a shorter time

\footnotetext{
${ }^{1}$ In this article, the market access countries approach applies to only four countries: Botswana, Gabon, Mauritius and South Africa.

${ }^{2}$ In 2006, 2009, 2012 and 2017.
} 
horizon this may not be the case and therefore liquidity indicators are also monitored. These are based on several measures of debt service ratios, which capture the availability of liquid financial resources to face maturing commitments (IMF, 2013b). The DSF assesses the value of such indicators against indicative thresholds regarding both solvency and liquidity criteria. These are contingent on several variables, the most important of which has traditionally been the institutional quality of the country, as measured by the Country Policy Institutional Assessment (CPIA). ${ }^{3}$ The latest IMF review suggests that this assessment be augmented with currency reserves coverage, world growth, remittances and country growth, and that the baseline debt projections be subject to new realism tools (IMF, 2017a).

This comparison may result in debt indicators falling above or below the indicative thresholds under baseline or stress-test scenarios, and a resultant risk signal is provided (low, moderate or high) based upon any breaches to the thresholds. The most important result of this process is the external risk rating, which is assigned by comparing projected evolution of the external debt indicators that relate to public and publicly guaranteed debt under baseline and stress-test scenarios to respective thresholds, which are dependent primarily on the debtcarrying capacity assigned under the CPIA. According to the breaches observed, a low, moderate or high risk rating is applied. The external risk rating has operational significance since it is formally used by the World Bank and IMF to help determine lending policies for low-income countries.

The DSF has been criticized for its assumptions, inputs and mechanisms employed. Critics have questioned the robustness and legitimacy of the CPIA to classify countries' debtcarrying capacity (Nissanke, 2013; Van Waeyenberge, 2009). Debt sustainability, for example, depends on the projections about the evolution of future variables and the accuracy of these projections has been critiqued (Guzman and Heymann, 2016; Luna, 2014). Indeed, these same projections have been criticized for being employed in an unduly mechanistic way, via stress tests on baseline scenarios, which often do not take into account feedback mechanisms from government responses (Martin, 2015; Wyplosz, 2009), ${ }^{4}$ prompting efforts to incorporate interactions between the macro variables that are shocked (IMF, 2017a). In

\footnotetext{
${ }^{3}$ The CPIA indicators are based on Kraay and Nehru (2004). The re-estimated thresholds after the 2012 DSF revision can be found in IMF (2013b). [What does 'these' refer to? Indicators? Thresholds? Variables? SPECIFIED]

${ }^{4}$ A related criticism is that the magnitude of such stress tests is based on historical averages, which is not appropriate when talking about developing countries, whose economic structure is rapidly changing (Nissanke, 2013).
} 
practice, the DSF has a limited ability to predict actual debt problems (IMF, 2016b: 7). ${ }^{5}$ One possible change to address such failings is the more generalized introduction of a probabilistic approach (Berg et al., 2014) partially included for borderline cases after the DSF's 2012 review (IMF, 2013b).

The inclusion of more country-specific variables in the underlying methodology that generates the risk rating - as opposed to relying on the broad averages of low-income countries - seems sensible, although the complexity generated has raised concerns about usability (Martin, 2015) and the IMF (2017a) notes such variables were only sparsely utilized since the last review. A fourth long-standing criticism is the lack of consideration of private sector debt (IMF, 2016a). The key indicator in the DSF, the external risk rating, although emergent from an external debt sustainability analysis which includes public and publicly guaranteed (PPG) external debt and private non-guaranteed (PNG) external debt, is informed solely from the PPG external debt, with the reason given that historically this was the largest source of external risk (IMF, 2013b). Nevertheless, contingent liabilities arising from private sector borrowing could impact public finances, making the excessive reliance on PPG external debt less meaningful. An additional risk rating, the overall risk rating, is also produced to capture risks related to private external or public domestic debt, an innovation welcomed by many civil society organizations (IMF, 2016a). This, however, has no formal operational significance for lending and policy prescriptions and has been only sporadically used since its inclusion (IMF, 2017a).

The latest proposal for reform in 2017 (ibid.) recognizes that the DSF lacks the tools to assess market-financing shocks. To this end the IMF proposes to introduce a tool to detect vulnerability arising from market financing conditions that may worsen roll-over risk in countries where short-term debt maturities increase market exposure (ibid.). The tool develops benchmarks for two indicators, gross financing needs and Emerging Market Bond Index (EMBI) spreads, which when breached would signal heightened liquidity needs, in particular difficulties in public sector financing. However, once again, the ultimate classification of the external risk rating is not informed by these benchmarks, but only supports better judgement of the risks a country faces (ibid.).

\footnotetext{
${ }^{5}$ Of the countries that experienced debt distress over the past few years, in only a few cases was the relevant debt distress indicator high in the year preceding the debt distress event. The IMF plans to simplify the DSF template in order to assess more accurately the risk of debt distress (IMF, 2016b).
} 
Finally, an overarching critique regarding the interpretation of results of the debt sustainability assessments concerns the conditionality reforms that accompany IMF and World Bank programmes. Typically, the mandated reforms focus solely on a contraction of domestic demand, mainly through fiscal consolidation, with a corollary shrinkage of domestic incomes, in order to reduce indebtedness and reverse balance of payment deficits (Killick, 1995). Such policies have been criticized for being pro-cyclical and have been linked to reductions in social expenditure and increases in poverty, since they include wage and income policies as part of an array of broad reforms mandated by the institutions (Kentikelenis et al., 2016; Oberdabernig, 2013).

In sum, the DSF, while not impermeable to criticism as the latest rounds of revisions show (IMF, 2016b, 2016c, 2017a), remains insufficiently equipped to tackle operationally the changing contemporary reality of sub-Saharan African debt sustainability. In particular, for reasons we develop below, low-income countries and the DSF still miss the crucial importance of global liquidity affecting the behaviour of private lenders and investors towards debt in sub-Saharan Africa, as well as the deeper implications of private sector indebtedness. ${ }^{6}$ We turn to this in the next section.

\section{GLOBAL LIQUIDITY AND PUBLIC AND PRIVATE DEBT INTERDEPENDENCE}

The DSF faces some fundamental analytical challenges. It remains tied to the traditional view that trade dynamics govern debt in sub-Saharan Africa. As exemplified by Moss (2006: 5) 'the most important factor in the emergence of the African debt problem has been the underlying lack of expansion in real income of exports'. The volatility of export earnings has been linked to commodity price cycles which greatly affect the sustainability indicators that are linked to export earnings (Leo, 2009; Muhanji and Ojah, 2011). The most recent Regional Economic Outlook published by the IMF (2017b) highlights the recent rise in external debt, predominantly due to export revenue decreases and thus greater current account deficits. External deficits are closed through conditionality policies that include contraction of income

\footnotetext{
${ }^{6}$ For the few sub-Saharan African countries following the market access countries (MAC) approach, this is slightly different. The MAC approach does take into account the debt profile, including the proportion of domestic debt that is owned by foreign investors. However, private sector borrowing is still not directly captured and global liquidity is not featured among the macro-financial shocks at the core of the MAC assessments. Furthermore, as it will be shown, many countries still under the framework for low-income countries have in fact become more financially integrated.
} 
via pro-cyclical fiscal consolidation, without heed to the negative consequences brought by the concomitant contraction in domestic demand.

The prevalent focus on current accounts as the key determinant of debt sustainability, grounded in basic national accounting identities, can be misleading, and can potentially misconstrue the nature of international debt-related flows. International lending and borrowing result in gross monetary flows, which determine debt as a transnational monetary claim on financial assets, as opposed to a claim on real resources. All international monetary transactions, including debt servicing, require financing (i.e. cash flows) rather than saving (i.e. unspent income). ${ }^{7}$ While such cross-border cash flows may originate from trade in goods and services, they are not, in principle, necessarily related to any particular real economic activity.

Whether a debt is sustainable therefore depends not only on cash flows from export earnings, but also, crucially, on the willingness of lenders to finance and especially refinance it. A country that is unable to refinance its debt, or one that can only do so at very high interest rates or at very short maturities, can potentially be forced to default on its obligations, regardless of its current account or government budget deficit. ${ }^{8}$ Of course, in conditions of perfectly closed financial accounts, being able to finance a debt becomes roughly equivalent to having a balanced current account (net of any change of currency reserves). But such a perspective becomes questionable when looking at the contemporary reality of financial openness and integration. The work of Lane and Milesi-Ferretti (2003, 2007, 2018) documents an exceptional expansion of cross-border asset holdings over the past two decades that increasingly involves low- and middle-income countries, including, as we will show, some sub-Saharan African countries. A myriad of private agents conducts daily financial transactions through increasingly liberalized markets so that gross cross-border holdings and financial flows are several orders of magnitude bigger than their corresponding net figures. Debt sustainability therefore hinges on private actors' behaviour in relation to the financing of countries' external debt because those actors' transactions determine the cash flows from which debts are serviced.

\footnotetext{
${ }^{7}$ These views have been recently put forward by a number of authors (Bonizzi, 2017b; Borio and Disyatat, 2011, 2015), but can be traced further back to Keynes and the 'liquidity' approach to finance (Keynes, 1937).

${ }^{8}$ Under the assumption that such a debt is denominated in foreign currency, which is largely the case in sub-Saharan Africa.
} 
It does not follow that current account deficits are irrelevant to debt sustainability. The size of the current account deficit affects private actors' willingness to refinance debt. Furthermore, a large current account deficit makes the adjustment process that follows a debt default more painful for the domestic economy, because, in the absence of debt financing, private agents and the government may find themselves deprived of the foreign currency to pay for imports and thus are forced to contract spending. Nevertheless, a current account deficit per se is neither a necessary nor a sufficient condition to determine the (un)sustainability of debt.

A primary determinant of private actors' behaviour regarding debt financing, and thus a determinant of debt sustainability in sub-Saharan Africa, is the fluctuation of liquidity of global markets. There is no consensus as to the ultimate causes of movements of global liquidity, ${ }^{9}$ as it depends on the extent to which both public and private agents are prepared to extend financing internationally (Eickmeier et al., 2013; Landau, 2013). In the post-financial crisis era, global liquidity has expanded primarily as a result of US and other major central banks' expansionary monetary policy — characterized by low interest rates and quantitative easing — that has induced a search for yield by global investors, generating spillovers throughout the emerging and developing world (Chen et al., 2012; Fischer, 2015; Rey, 2013; Shin, 2012, 2013).

Ample global liquidity eases the sustainability of debt. Under such conditions borrowers in sub-Saharan Africa and elsewhere can easily refinance their debts, by accessing funds at low interest rates and long-term maturities. Additionally, global liquidity tends to appreciate developing countries' currencies, as it draws capital inflows, thus lowering the burden of foreign currency debts. Conversely, developing countries become exposed to the risk of liquidity shrinkages in the future (Akyüz, 2017; Bonizzi, 2017a; Kaltenbrunner, 2010; Kaltenbrunner and Painceira, 2015, 2017). Should global liquidity contract, tougher financing conditions, including higher interest rates and depreciating currencies, could lead countries into debt distress and render debt unsustainable.

Fluctuations in global liquidity also drive changes in private sector external debt. These changes may then generate pressure on the sustainability of public sector debt through three primary mechanisms. First, private sector external indebtedness affects the foreign currency reserves position of a country. Although foreign currency reserves are an asset of the government, they hedge not only the foreign indebtedness of the government, but also of the

\footnotetext{
${ }^{9}$ See Borio (2016) for a discussion of this.
} 
private sector, in the sense that the private sector may, indirectly, rely on those reserves. Should private sector payments to foreign lenders rise, governments may face the dilemma of intervening in the currency markets, de facto allowing private borrowers to draw on such reserves, or trying to keep their reserves untouched, thereby devaluing the currency. Both options have significant consequences for debt sustainability, with the former leading to exhaustion of reserves and the latter leading to destabilization of the value of domestic currency. While the value in the domestic currency unit of foreign currency reserves may increase as a result of the devaluation of domestic currency, the value of external government borrowing would also rise pro rata, increasing the domestic burden of debt.

Second, governments cannot totally disregard the external borrowing of their private sector. In small dual-sector developing countries, where the more dynamic modern sector is more integrated with foreign markets, large private businesses are likely to be 'systemic' in the sense that a breakdown in their private external debt payments may have severe effects on the business cycle. Such structural links between governments and the private sector have been reinforced by policies of privatization and growing public-private cooperation in financing arrangements, such as public-private partnerships and 'blended' private financial resources with development assistance (Bonizzi et al., 2015; Martin, 2015; Van Waeyenberge, 2015). A government may even come under pressure from governments of countries where creditor banks are based to take over the management of the private sector debt. As UNCTAD (2015b) warns, historically low public debt is not a reason for complacency in light of rapid rises of private sector debts, considering the frequency and historical precedent with which these get nationalized in times of crisis.

Third, sovereign debt sustainability depends on the extent to which the government is able to use the foreign currency inflows from increasing private sector indebtedness to replace its own foreign currency debt with domestic currency debt. ${ }^{10}$ While this eases the burden of public sector debt, by converting it into domestic currency, the process is conditional upon rising private sector foreign currency indebtedness. In the case of a retreat of foreign lending to the private sector, governments cease to be able to use private sector capital inflows to

\footnotetext{
${ }^{10}$ In a boom, a country's private sector is able to attract portfolio flows and loans. The foreign currency counterpart of this is deposited in the domestic banking system, in exchange for the local currency to buy financial securities. The government issues domestic securities whose proceeds are used to buy the foreign currency in the domestic banking system. The government then uses the foreign currency to repay its foreign currency borrowing, as illustrated by the case of Mexico at the end of the 1980s (Toporowski, 2014).
} 
refinance government foreign debt into local currency and may be forced to take up foreign currency debt on unfavourable terms.

In sum, external debt sustainability, in conditions of increasing financial openness and integration, does not depend solely and directly on current account positions or fiscal balances. Instead, it is contingent on the state of global liquidity, and the systemic interplay of private sector debt with sovereign debt, which makes private indebtedness appear as a problem of fiscal sustainability in times of crisis. Such considerations remain insufficiently appreciated by the current version of the DSF. In the rest of this article we will empirically show why these are relevant for sub-Saharan Africa.

\section{PRIVATE ACTORS AND EMERGING FINANCIAL INTEGRATION IN SUB- SAHARAN AFRICA}

According to the DSF, currently only four countries in sub-Saharan Africa - Botswana, Gabon, Mauritius and South Africa — are defined as having market access. However, as this section will show, the extent of financial integration goes beyond what the distinction between the market access and low-income frameworks accords. To demonstrate this, we study the external debt statistics of 35 countries in sub-Saharan Africa contained in the World Bank's International Debt Statistics (IDS) database. ${ }^{11}$

As shown in Figure 1, the debt profile of the region has changed substantially over the past 15 years. Crucial to this change has been the increasing presence of private actors in subSaharan Africa's debt markets, both as borrowers and as lenders. The rise of private lenders is seen in the reshaping of the PPG debt composition via the rise of private participation in sub-Saharan Africa's public borrowing. Official creditors (bilateral and multilateral) accounted for about 80 per cent of total external debt in 2000 but in 2014 they only accounted for about 44 per cent. The presence of private creditors in PPG debt has increased from 15 per cent to about 30 per cent of total external debt in the same period, driven mostly by an expansion in sovereign bond markets, whose total market capitalization at the end of 2015 stood at US\$ 73 billion.

\footnotetext{
${ }^{11}$ See Appendix for details. The following figures refer only to long-term external debt, since shortterm debt figures in the World Bank's IDS database do not allow for a distinction between private and public lenders.
} 
[Insert Figure 1 here]

The rise of private borrowers is seen through the increased external borrowing of subSaharan Africa's private sector. Between 2000 and 2015 the importance of PNG debt has been growing from a very small proportion (about 6 per cent) to about a quarter of total external debt in 2015. While about 80 per cent of this is commercial bank debt, private sector bonds outstanding have grown over the period, from US\$ 1.3 to 15 billion (or from under 1 per cent of total external debt to 5 per cent of total external debt). In comparison to means to pay, on average for the region PNG bonds grew from 2 per cent of exports and 5 per cent of reserves in 2000 to 6 per cent of exports and 12 per cent of reserves in 2015.

The growing presence of private actors is indicative of the emerging financial integration of sub-Saharan Africa. Public and private debt in sub-Saharan Africa has become part of the investable world of global investors. As of 2016, a total of 15 countries $^{12}$ accessed international bond markets in the region, most for the first time (Sy, 2015; Tyson, 2015). The importance of the region in global markets is testified by inclusion of sub-Saharan African debt in leading J.P. Morgan bond indices: the US dollar denominated EMBI index and the local currency bond index Government Bond Index-Emerging Markets (GBI-EM). ${ }^{13}$ Similarly, corporate bonds have been issued by four countries - Angola, Ghana, Nigeria and South Africa - whose private issuers have become part of internationally traded indices. ${ }^{14}$ In some cases, this has been a deliberate policy design: Nigeria's 2011 US dollar bond issuance had three strategic objectives: (1) ensuring Nigeria's presence in the international market; (2) helping to attract foreign direct investment by increasing information disclosure; and (3) providing a benchmark for sovereign, subnational and corporate issuances (Meccagni et al., 2014). Thus, although sub-Saharan Africa remains a small component of global financial markets, it has emerged as a potentially attractive market for foreign lenders and investors.

\footnotetext{
${ }^{12}$ All countries in our financially connected (FC) group plus Ethiopia and Rwanda.

${ }^{13}$ See for example this fund by J.P. Morgan, which includes the benchmark allocation of the EMBI index:

www.jpmorganassetmanagement.lu/en/showpage. asp $x$ ?pageid $=44 \&$ fundid $=22 \&$ shareclassid $=7605$ and this fund, which is benchmarked to the GBI-EM index:

$\mathrm{http} / / / \mathrm{www} . j p m o r g a n a s s e t m a n a g e m e n t . l \mathrm{l} / \mathrm{en} /$ showpage. aspx ?pageid $=44 \&$ FundID $=6152 \&$ ShareclassI $\mathrm{D}=7250$

${ }^{14}$ The Corporate Emerging Markets Bond Index (CEMBI) by J.P. Morgan includes companies from those four countries (www.ishares.com/us/products/239525/).
} 
This can be seen in Figure 2 which presents data of flows and holdings of sub-Saharan African bonds intermediated by mutual funds. It is evident that monthly flows become much more substantial overtime. For example, in June 2013 alone there were outflows of more than US\$ 1 billion from the region's bond markets. As a comparison, in October 2008, at the peak of the Lehman Brothers crisis, the outflows were about US\$ 350 million. Flows to African bond markets have been positive in most months since the crisis, with dips in the second half of 2011 and 2013. As a result, asset holdings - which also include capital and currency gains - soared to about US\$ 26 billion at the end of October 2013. This is more than a third of the size of the bond markets, indicating a substantial participation of foreign asset managers in African bond markets. The oversubscription by foreign investors of many bond issuances is a clear demonstration of high demand of the asset class by return-seeking investors (Olabisi and Stein, 2015).

\section{[Insert Figure 2 here]}

Not all countries in sub-Saharan Africa have been equally affected by this process; official lenders remain the main creditors of external debt in the majority of them. To better account for this heterogeneity we split our sample into two groups. Mirroring UNCTAD's definition of commodity dependence, we define countries as financially connected (FC) if their reliance on official debt is less than 60 per cent. The results of this division show that the presence of private actors is increasingly sizeable only in the FC group. In non-FC countries the median proportion of official PPG debt to total external debt remains close to 80 per cent, declining only slightly since the turn of the century (as shown in Figure 3). In FC countries on the other hand more than half of external debt involves a private actor, and about 15 per cent on average is PNG debt, compared to 0.5 per cent in non-FC countries. ${ }^{15}$

\section{[Insert Figure 3 here]}

The growing interest in sub-Saharan African debt by global private investors is concentrated within a group of 11 countries. While still a minority of countries within the

\footnotetext{
${ }^{15}$ This is in line with the recent study by Presbitero et al. (2016), which shows that developing countries that have access to international capital markets are typically larger, with higher GDP per capita, and lower initial levels of indebtedness, which broadly corresponds to the profile of our FC group.
} 
region, this is a significantly larger group compared to the MAC classification. ${ }^{16}$ The classification into low-income countries and MAC thus partly misses the dynamic involvement of private actors in several countries' debt markets. In the next section, we show how identifying this pattern is crucial to monitoring where problems to sustainability may arise.

\section{DEBT SUSTAINABILITY AND FINANCIAL INTEGRATION}

Taking a long-term perspective, debt sustainability across several countries in sub-Saharan Africa has been characterized by a generalized improvement. Positive growth rates ${ }^{17}$ and debt relief initiatives, such as the Highly-Indebted Poor Country (HIPC) and the Multilateral Debt Relief initiatives, led to a decline in the size and the burden of external debt in the 2000s. Indeed, where countries are classified according to their HIPC status, ${ }^{18}$ the importance of the debt-relief initiatives to reduce debt stocks in the 2000s is evident primarily through the decline of the solvency indicator (see Figure 4). The great wedge between the two groups prior to debt-relief initiatives has, however, narrowed, bringing the HIPC countries' debt indicators to broadly align with non-HIPC countries. Most importantly, signs of deterioration have been evident since 2012, and rose markedly in 2015 in both HIPC and non-HIPC countries. Debt relief, historically a key element, is less informative as a factor behind current debt dynamics in sub-Saharan Africa.

\section{[Insert Figure 4 about here]}

Current accounts and export dynamics are a key focus for the analysis of external debt sustainability in sub-Saharan Africa within the DSF. This works primarily through the impact of commodity prices. Commodities account for more than 60 per cent of total exports on

\footnotetext{
${ }^{16}$ Eight countries that are included in our FC group are not market access countries according to the DSF. Our FC group does not include Botswana given its still very high reliance on official credit. See Appendix for a full list. [No explanation of what FI stands for... THIS WAS AN ERROR, IT SHOULD BE FC, AS AMENDED]

${ }^{17}$ Real GDP growth averaged 4 per cent yearly in the period 2000-11, including the global recession in 2009, based on World Bank WDI data. See https://datacatalog.worldbank.org/dataset/worlddevelopment-indicators

${ }^{18}$ See Appendix for further details.
} 
average throughout the 2000-14 period in 27 out of 35 countries in our sample, making them commodity dependent according to UNCTAD's definition (UNCTAD, 2014). Despite this close-to-universal dependence within our sample, there is considerable heterogeneity with respect to the importance of commodity exports for different economies. We therefore divide our sample between those countries that are commodity dependent and where exports constitute an important component of GDP, which we call commodity exporters (CE) and the rest (non-CE). This type of distinction appears clearly in recent accounts of sub-Saharan Africa's prospects, featuring prominently in the IMF's recent Regional Economic Outlooks database (IMF, 2017b), which describes a heterogeneous economic path between countries that are commodity exporters as compared to those that are less resource intensive. Net commodity importers or countries with a low reliance on commodity exports as a component of their economy are likely to see their prospects improved (see Battaile et al., 2015; IMF, 2017a). These trade dynamics are reflected in UNCTAD's trade balances data: ${ }^{19} \mathrm{CE}$ countries had a substantial trade surplus of about 8-10 per cent to GDP until 2012, which then fell dramatically to a small deficit in 2015, while non-CE countries had a sizeable and growing deficit throughout the period 2000-15 that has moderately improved since 2012.

These different trade dynamics cannot, however, be easily linked to the debt sustainability indicators. As shown in Figure 4, the solvency and liquidity indicators in commodity exporting $(\mathrm{CE})^{20}$ countries have deteriorated since the global financial crisis, especially in 2014-15 as the trade balance deteriorated sharply. However, the non-CE group has not benefited from the fall in commodity prices, with DSF indicators worsening in the same period. Similarly, another key transmitter of export shocks to debt sustainability, the exchange rate, also shows mixed evidence of the impact of commodity prices. Exchange rate depreciation vis-à-vis the US dollar increases the real value of dollar external debt and therefore the domestic burden of debt. ${ }^{21}$ Commodity exporters' currencies tend to be positively correlated with commodity prices (see, for example, Chen et al., 2010). Figure 5 suggests that for several countries in sub-Saharan Africa such a relationship seems to exist, since most CE countries' currencies appreciated in the commodity price boom period (200508) and have been depreciating since 2011. However, some non-CE countries' currencies,

\footnotetext{
${ }^{19}$ See https://unctadstat.unctad.org/wds/ReportFolders/reportFolders.aspx

${ }^{20}$ See details in the Appendix.

${ }^{21}$ Although the currency composition of PPG debt has changed, debt denominated in US dollars still constitutes the majority of external debt - about 60 per cent of the total - a proportion that has increased since the crisis at the expense of the Euro and other advanced currencies.
} 
such as the South African Rand, have also depreciated sharply. Conversely, Cote d'Ivoire, a CE country, only experienced a minor depreciation.

\section{[Insert Figure 5 about here]}

In light of the theoretical discussion earlier in this article, it is not surprising that there is no straightforward link between commodity prices, current accounts and the deterioration of debt sustainability indicators. Borrower and lender behaviour ultimately determine the dynamics of debt as a monetary relation. While 'real' factors are significant influences in this process, monetary and financial dynamics are also important, increasingly so in conditions of financial integration.

Dividing the sample of countries by the criterion of FC or non-FC countries is highly informative in exploring the changes in debt sustainability. It is important to note that the sample splits almost evenly between CE ( 6 countries) and non-CE ( 5 countries) as well as HIPC ( 6 countries) and non-HIPC ( 5 countries). Overall, both FC and non-FC groups had trade deficits throughout the period, although the deficit in non-FC countries was higher. ${ }^{22}$ While FC countries have historically had lower debt levels, the post-crisis deterioration of their debt ratios compared to the non FC-group is significant: looking at Figure 4, the FC group is the only group where indicators clearly deteriorated since 2008. Although starting from different levels, between 2008 and 2015 the PPG external debt to export ratio increased from approximately 20 per cent to 79 per cent in the FC group, while barely increasing from 86 per cent to 93 per cent in the non-FC group. The corresponding liquidity indicators grew (that is, deteriorated) from 2.4 per cent to 3.5 per cent in FC countries, but declined from 3.2 per cent to 3.1 per cent in non-FC countries.

Further evidence of the significance of financial integration is seen when a two-sample ttest for equal mean is performed to show which categorization is the most meaningful to understand recent debt deterioration. As the results in Table 1 clearly show, FC countries show a statistically significant higher mean in the changes of both DSF liquidity and solvency indicators to exports in the post-2008 period, compared to non-FC countries. The CE/non-CE categorization on the other hand does not produce statistically significant tests.

\footnotetext{
${ }^{22}$ Authors' calculation based on UNCTAD's statistical database. See https://unctadstat.unctad.org/wds/ReportFolders/reportFolders.aspx
} 


\section{[Insert Table 1 here]}

The emerging process of financial integration is therefore crucial to the recent evolution of sub-Saharan Africa's debt and its sustainability. As discussed, this implies that financing conditions become heavily susceptible to the shifts of global liquidity, which are in turn heavily influenced by changes in US monetary policy (Chen et al., 2012; Rey, 2013; Shin, 2012). ${ }^{23}$ Three indicators are used to investigate the change of global liquidity. The first indicator is the expected Treasury Bill (T-Bill) Rate, as this captures the expectations of future monetary policy and funding conditions and is therefore a forward-looking indicator of global liquidity. The second is the 'shadow' Federal Funds rate, developed by Wu and Xia (2016): unlike the official target rate, the shadow rate can go below the zero lower bound, and thus captures the additional expansionary effect of unconventional monetary policy. The third indicator is the Volatility Index (VIX), which measures the implied volatility that investors expect from the S\&P 500 index. As discussed, beside monetary policy, global liquidity also depends on private actors' appetite for risk, and the VIX is frequently used as an indicator of investors' confidence: higher levels mean high expected volatility, lower investors' risk appetite, and therefore limited provision of global liquidity.

Figure 6 displays the volatility of global liquidity through the evolution of these three indicators. From 2009, the shadow federal funds rate and the expected T-Bill rates kept falling until mid-2014. Since then, however, the tapering and unwinding of quantitative easing has driven a clear policy tightening, which culminated in the FED funds target rise that happened in December 2015 (FOMC, 2015). The VIX also remained relatively flat between July 2011 - after the peak of the Eurozone crisis - and the middle of 2015, where the spike indicates a contraction of global investors' risk appetite. These measures evidence ample provision of global liquidity in the post-crisis environment, but a clear contraction in 2015 .

\section{[Insert Figure 6 about here]}

The impact of global liquidity on sub-Saharan African financing conditions is clear when looking at Figure 7. This shows the sovereign bond yield spread over global bond yields for

\footnotetext{
${ }^{23}$ Investors may also have systematic bias against particular markets. As reported by Olabisi and Stein (2015) and Presbitero et al. (2016), African countries pay higher interest rates than could be warranted by their fundamentals at all times, reflecting the general 'distrust' of African governments as debtors.
} 
selected sub-Saharan African countries - all part of the FC group except Rwanda. These increased markedly over the course of 2015, as global liquidity contracted (except in Rwanda, the only non-FC country, where the increase was noticeably smaller).

[Insert Figure 7 about here]

Correlation coefficients also testify to the impact of global liquidity on bond spreads (see Table 2). There is a significant positive correlation between bond spreads and the VIX index and the expected $\mathrm{T}$ Bill rate, ${ }^{24}$ a result in line with other recent findings (Presbitero et al., 2016). Rwanda, a non-FC country, displays the lowest correlation with both, showing that global liquidity affects financing conditions in all countries, but this occurs in FC countries to a much greater extent. Most importantly, it is only in FC countries where private actors have a sizeable presence that these factors translate into economically significant impacts on debt sustainability indicators: in Rwanda official debt is almost 75 per cent, resulting in a smaller impact of global liquidity on total debt burdens.

\section{[Insert Table 2 about here]}

This section has thus evidenced that the recent evolution of debt sustainability in the FC group has been seriously affected by the state of global liquidity. The ability of both private and public sectors in certain larger and more connected African countries to access private sector credit is a product of the easy liquidity conditions that emerged in the post-crisis era. Low borrowing costs and ample liquidity induced many countries in sub-Saharan Africa to tap into global capital markets, in some cases leading the way for their own private sector to do the same. The emerging signs of reversal of the current global liquidity cycle reveal potential side-effects of such a strategy, as global investors start demanding higher spreads, reducing their exposure to 'frontier' markets (including sub-Saharan Africa). This testifies to the extent to which the region has become exposed to new vulnerabilities, as a result of financial integration (Akyüz, 2017; Kaltenbrunner and Painceira, 2015, 2017).

These processes, over which countries in sub-Saharan Africa have no control, remain insufficiently appreciated in the DSF whose indicators remain static with respect to changes

\footnotetext{
${ }^{24}$ Correlation with the Wu-Xia shadow rate is not shown, as the monthly frequency of this variable would make the sample size too small.
} 
in global liquidity. Even the framework for assessing debt sustainability for market access countries (MAC-DSA), which as indicated only applies to four countries in our sample, does not include global liquidity among its key scenario shocks. The latest review of the DSF has highlighted this point, suggesting a greater role for liquidity considerations (IMF, 2017a). At present, however, this has yet to be operationalized.

\section{CONCLUSION}

Recent evolution of debt sustainability indicators in sub-Saharan Africa can be most cogently explained by the degree of participation of private lenders and borrowers in the region's debt structures. This has been the product of a partial contraction of the global liquidity cycle, as indicated by the co-movement between bond spreads, global indicators of risk appetite and expected changes in monetary policy. At the same time the private sector has extended its foreign borrowing, raising concerns about its future interplay with growing public debt. The current DSF still takes a country-based, static view and is unable to fully take these dynamics into account.

While we do not offer specific technical 'solutions', we can suggest ways in which global liquidity can be incorporated into sustainability assessments. The first is to allow for additional flexibility during crises which could be done by making debt thresholds dynamic rather than static. Thresholds and indicators need to be counter-cyclically linked to global liquidity conditions, so that the DSF can be used as a way to 'lean against the wind' - all the more so since Basel III imposes higher constraints on bank lending and as the Federal Reserve moves away from quantitative easing. In conditions of expanding/shrinking global liquidity, debt thresholds should be more/less stringent. This could partly counter the boombust dynamics originating in debt markets. Secondly, private sector debt should be more effectively accounted for. This means including a more detailed assessment of contingent liabilities as well as the impact of private sector debt on foreign exchange reserves and the ability of governments to refinance their debt in domestic currencies through the influx of credit to the private sector from abroad. Importantly, it should also induce policy actions to tackle debt within the private sector, rather than considering it a fiscal policy problem. The most recent IMF review (2017a) addresses aspects of these concerns, though it remains to be seen how meaningfully these will be operationalized. 
We remain sceptical, however, as to whether technical fixes to the underlying methodology of constructing the thresholds are enough to adequately protect low-income countries from deteriorating economic situations arising from a volatile external environment. If a global liquidity squeeze pushes more countries into higher risk brackets, the onus of dealing with this consequence falls on the debtor country. To the extent that debt sustainability in sub-Saharan Africa is partly determined globally rather than locally, it requires global solutions. As discussed, no consensus exists as to the ultimate cause of global liquidity cycles, but nonetheless policy coordination, including that on regulation in the key global financial centres, is crucial for their management. We maintain that debt sustainability in sub-Saharan Africa is, to an increasingly important extent, contingent on the successful implementation of such policy coordination.

[Insert Appendix here]

\section{REFERENCES}

Adams, P. (2015) Africa Debt Rising. London: African Research Institute.

Aglionbi, J. (2016) 'African Development Bank Chief Warns Africa on International Debt',

Financial Times 30 August. www.ft.com/content/6c7f0094-6d57-11e6-a0c9$1365 \mathrm{ce} 54 \mathrm{~b} 926$

Aizenman, J., M. Binici and M. Hutchison (2014) 'The Transmission of Federal Reserve Tapering News to Emerging Financial Markets'. NBER Working Paper No. 19980. Cambridge, MA: National Bureau of Economic Research.

Akyüz, Y. (2017) Playing with Fire: Deepened Financial Integration and Changing Vulnerabilities of the Global South. Oxford: Oxford University Press.

Battaile, B., F.L. Hernandez and V. Norambuena (2015) 'Debt Sustainability in Sub-Saharan Africa, Unravelling Country Specific Risks'. Policy Research Working Papers No. 7523. Washington, DC: World Bank.

Berg, A., E. Berkes, C. Pattillo, A.F. Presbitero and Y. Yakhshilikov (2014) 'Assessing Bias and Accuracy in the World Bank-IMF's Debt Sustainability Framework for Low-income Countries'. IMF Working Papers WP/14/48. Washington, DC: International Monetary Fund. 
BIS (2013) 'Global Liquidity: Where Do We Stand?'. Speech by Jaime Caruana, General Manager of the Bank for International Settlements, Bank of Korea International Conference on 'Assessing Global Liquidity in a Global Framework', Seoul (4 June). www.bis.org/speeches/sp130604.htm

Bonizzi, B. (2017a) 'International Financialization and the Contradictions of Privatized Keynesianism', Economic and Political Studies 5(1): 21-40.

Bonizzi, B. (2017b) 'An Alternative Post-Keynesian Framework for Understanding Capital Flows to Emerging Markets', Journal of Economic Issues 50(1): 137-62.

Bonizzi, B., C. Laskaridis and J. Toporowski (2015) 'EU Development Policy and the Promotion of the Financial Sector'. FESSUD Working Paper Series No. 120. Leeds: Financialisation, Economy, Society and Sustainable Development, Leeds University Business School.

Borio, C. (2016) 'More Pluralism, More Stability'. BIS presentation at the Seventh Highlevel SNB-IMF Conference on the IMF, Zurich (10 May).

Borio, C. and P. Disyatat (2011) 'Global Imbalances and the Financial Crisis: Link or No Link?’. BIS Working Paper No. 346. Basel: Bank for International Settlements.

Borio, C. and P. Disyatat (2015) 'Capital Flows and the Current Account: Taking Financing (More) Seriously'. BIS Working Paper No. 525. Basel: Bank for International Settlements. Chen, Y., K. Rogoff and B. Rossi (2010) 'Can Exchange Rate Forecast Commodity Prices?', Quarterly Journal of Economics 125(3): 1145-94.

Chen, Q., A. Filardo, D. He and F. Zhu (2012) International Spillovers of Central Bank Balance Sheet Policies. Basel: Bank for International Settlements.

Eickmeier, S., L. Gambacorta and B. Hofmann (2013) 'Understanding Global Liquidity’. BIS Working Papers No. 402. Basel: Bank for International Settlements.

Fischer, A. (2015) 'The End of Peripheries? On the Enduring Relevance of Structuralism for Understanding Contemporary Global Development', Development and Change 46(5): 700-32.

FOMC (2015) 'Monetary Policy'. Federal Open Market Committee press release (16 December). Washington, DC: Federal Reserve Bank.

Gabor, D. (2010) 'The International Monetary Fund and its New Economics', Development and Change 41(5): 805-30.

Güven, A.B. (2012) 'The IMF, the World Bank, and the Global Economic Crisis: Exploring Paradigm Continuity', Development and Change 41(4): 869-98. 
Guzman, M. and D. Heymann (2016) 'The IMF Debt Sustainability Analysis: Issues and Problems'. IIEP Working Paper No. 9. Buenos Aries: Instituto Interdisciplinario de Economía Política IIEP-Baires.

IMF (2013a) 'Staff Guidance Note for Public Debt Sustainability Analysis in Market-access

Countries'. Washington, DC: International Monetary Fund

IMF (2013b) 'Staff Guidance Note on the Application of the Joint World Bank-Fund Debt

Sustainability Framework for Low-income Countries'. Washington, DC: International Monetary Fund.

IMF (2016a) 'Comments for the Online Consultation: Civil Society Position on the IMF and

World Bank Sustainability Framework Review'. Washington, DC: International Monetary Fund.

IMF (2016b) 'Review of the Debt Sustainability Framework for Low Income Countries:

Discussion Note'. Washington, DC: International Monetary Fund.

IMF (2016c) ‘Debt Crisis Prevention’. Inter-Agency Task Force on Financing for

Development Issue Brief Series (July). Geneva: United Nations; Washington, DC:

International Monetary Fund.

IMF (2016) World Economic Outlook 2016. Washington, DC: International Monetary Fund

IMF (2017a) 'Review of the Debt Sustainability Framework in Low-income Countries:

Proposed Reforms'. Washington, DC: International Monetary Fund.

IMF (2017b) 'Regional Outlook: Sub-Saharan Africa. Fiscal Adjustment and Economic

Diversification'. Washington, DC: International Monetary Fund.

www.imf.org/en/Publications/REO/SSA/Issues/2017/10/19/sreo1017

IMF (2018) 'Macroeconomic Developments and Prospects in Low-income Developing Countries'. Washington, DC: International Monetary Fund.

Kaltenbrunner, A. (2010) 'International Financialization and Depreciation: The Brazilian

Real in the International Financial Crisis', Competition and Change 14(3-4): 296-323. Kaltenbrunner, A. and J.P. Painceira (2015) “"Developing Countries” Changing Nature of Financial Integration and New Forms of External Vulnerability: The Brazilian Experience', Cambridge Journal of Economics 39(5): 1281-306.

Kaltenbrunner, A. and J.P. Painceira (2017) 'The Impossible Trinity: Inflation Targeting, Exchange Rate Management and Open Capital Accounts in Emerging Economies', Development and Change 48(3): 452-80. 
Kentikelenis, A., T.H. Stubbs and L.P. King (2016) 'IMF Conditionality and Development Policy Space, 1985-2014', Review of International Political Economy 23(4): 543-82.

Keynes, J.M. (1937) 'Alternative Theories of the Rate of Interest', Economic Journal 47: $241-52$.

Killick, T. (1995) IMF Programmes in Developing Countries. London: Routledge.

Kraay, A. and V. Nehru (2004) 'When is Debt Sustainable?'. World Bank Policy Research Working Paper No. 3200. Washington, DC: World Bank.

Landau, J.P. (2013) 'Global Liquidity: Public and Private'. Paper presented at the Jackson Hole Symposium, Federal Reserve Bank, Jackson Hole, WY (22-24 August).

Lane, P.R. and G.M. Milesi-Ferretti (2003) 'International Financial Integration'. IMF Staff Papers No. 50 (January): 82-113.

Lane, P.R. and G.M. Milesi-Ferretti (2007) 'The External Wealth of Nations Mark II: Revised and Extended Estimates of Foreign Assets and Liabilities, 1970-2004', Journal of International Economics 73(2): 223-50.

Lane, P.R. and G.M. Milesi-Ferretti (2018) 'The External Wealth of Nations Revisited: International Financial Integration in the Aftermath of the Global Financial Crisis', IMF Economic Review 66(1): 189-222.

Leo, B. (2009) 'Will World Bank and IMF Lending Lead to HIPC IV? Debt Deja-vu All Over Again'. Working Paper No. 193. Washington, DC: Center for Global Development.

Luna, F. (2014) 'IMF Forecasts in the Context of Program Countries'. IEO Background Paper BP/14/05. Washington, DC: Independent Evaluation Office of the International Monetary Fund.

Martin, M. (2015) 'Input to Revision of the Low-income Country Debt Sustainability Framework'. DFI Report to DFID on Debt Sustainability Contract Number 40092291. London: Development Finance International.

Meccagni, M. et al. (2014) 'Issuing International Sovereign Bonds, Opportunities and Challenges for Sub-Saharan Africa'. IMF Working Paper WP/14/02. Washington, DC: International Monetary Fund.

Moss, T. (2006) ‘Will Debt Relief Make a Difference?’. Working Paper No. 88. Washington, DC: Center for Global Development.

Muhanji, S. and K. Ojah (2011) 'Management and Sustainability of External Debt: A Focus on the Emerging Economies of Africa', Review of Development Finance 1(3): 184-206. 
Nissanke, M. (2013) 'Managing Sovereign Debt for Productive Investment and Development in Africa'. SOAS Working Paper No. 19683. London: SOAS, University of London. https://core.ac.uk/download/pdf/42548480.pdf

Oberdabernig, D.A. (2013) 'Revisiting the Effects of IMF Programs on Poverty and Inequality', World Development 46: 113-42.

Olabisi, M. and H. Stein (2015) 'Sovereign Bond Issues: Do African Countries Pay More to Borrow?', Journal of African Trade 2(1-2): 87-109.

Presbitero, A.F., D. Ghura, O.S. Adedeji and L. Njie (2016) 'Sovereign Bonds in Developing Countries: Drivers of Issuance and Spreads', Review of Development Finance 6(1): 1-15.

Rakshit, M. (2009) 'The IMF on the Global Crisis and its Resolution', Development and Change 40(6): 1293-307.

Rey, H. (2013) 'Dilemma Not Trilemma: The Global Financial Cycle and Monetary Policy Independence'. Paper presented at the Jackson Hole Symposium, Federal Reserve Bank, Jackson Hole, WY (22-24 August).

Shin, H. (2012) ‘Global Banking Glut and Loan Risk Premium', IMF Economic Review 60: 155-92.

Shin, H. (2013) 'The Second Phase of Global Liquidity and its Impact on Emerging Economies'. Keynote Address, Asia Economic Policy Conference, Federal Reserve Bank of San Francisco, San Francisco, California (3-5 November).

Sy, A. (2015) 'Trends and Developments in African Frontier Bond Markets'. Policy Paper 2015-1. Washington, DC: Brookings Institution.

Toporowski, J. (2014) 'Two Principles of Debt and National Income Dynamics in a Pure Credit Economy'. Working Paper No. 187. London: Department of Economics, SOAS, University of London.

Tyson, J. (2015) Sub-Saharan Africa International Sovereign Bonds. London: Overseas Development Institute.

UNCTAD (2014) The State of Commodity Dependence 2014. Geneva: United Nations Conference on Trade and Development.

UNCTAD (2015a) 'Revisiting Debt Sustainability in Africa'. Note by the UNCTAD Secretariat, Trade and Development Board, 61st Executive Session of the United Nations Conference on Trade and Development, Geneva (24-26 June).

UNCTAD (2015b) Trade and Development Report 2015. Geneva: United Nations Conference on Trade and Development. 
UNCTAD (2016) Economic Development in Africa Report: Debt Dynamics and

Development Finance in Africa. New York: United Nations.

Van Waeyenberge, E. (2009) 'Selectivity at Work: Country Policy and Institutional

Assessments at the World Bank', The European Journal of Development Research 21(5): $792-810$.

Van Waeyenberge, E. (2015) 'The Private Turn in Development Finance'. FESSUD Working Paper Series No. 140. London: Financialisation, Economy, Society and Sustainable Development.

World Bank (2010) Global Economic Prospects. Washington, DC: World Bank.

World Bank (2016) International Debt Statistics 2016. Washington, DC: World Bank.

Wu, J.C. and F.D. Xia (2016) 'Measuring the Macroeconomic Impact of Monetary Policy at the Zero Lower Bound', Journal of Money, Credit and Banking 48(2-3): 253-91.

Wyplosz, C. (2009) 'Debt Sustainability Assessment: The IMF Approach and Alternatives'. IHEID Working Papers 03-2007. Geneva: Economics Section, The Graduate Institute of International Studies.

Wyplosz, C. (2011) 'Debt Sustainability Assessment: Mission Impossible', Review of Economics and Institutions 2(3): 1-37.

\section{[Insert author bio sketches]}

Bruno Bonizzi (brunobonizzi@gmail.com) is a Senior Lecturer in Finance at University of Hertfordshire Business School, London. He researches on financial integration and capital flows, financialization, and pension funds, particularly in the context of developing and emerging economies.

Christina Laskaridis (corresponding author; 217924@soas.ac.uk) is a Research Fellow at Duke University's Center for the History of Political Economy in Durham, North Carolina and a Doctoral Researcher in Economics at SOAS, University of London. Research interests include financial globalization, debt and monetary debates in historical perspective and the International Monetary Fund. 
Jan Toporowski (jt29@soas.ac.uk) is Professor of Economics and Finance at SOAS,

University of London. He specializes in monetary and financial economics, and he has just completed two volumes of biography of Michał Kalecki (Palgrave Macmillan, 2018). He has worked on African economies for various commercial and UN agencies. 
Figure 1. Long-term External Debt Composition, Sub-Saharan Africa

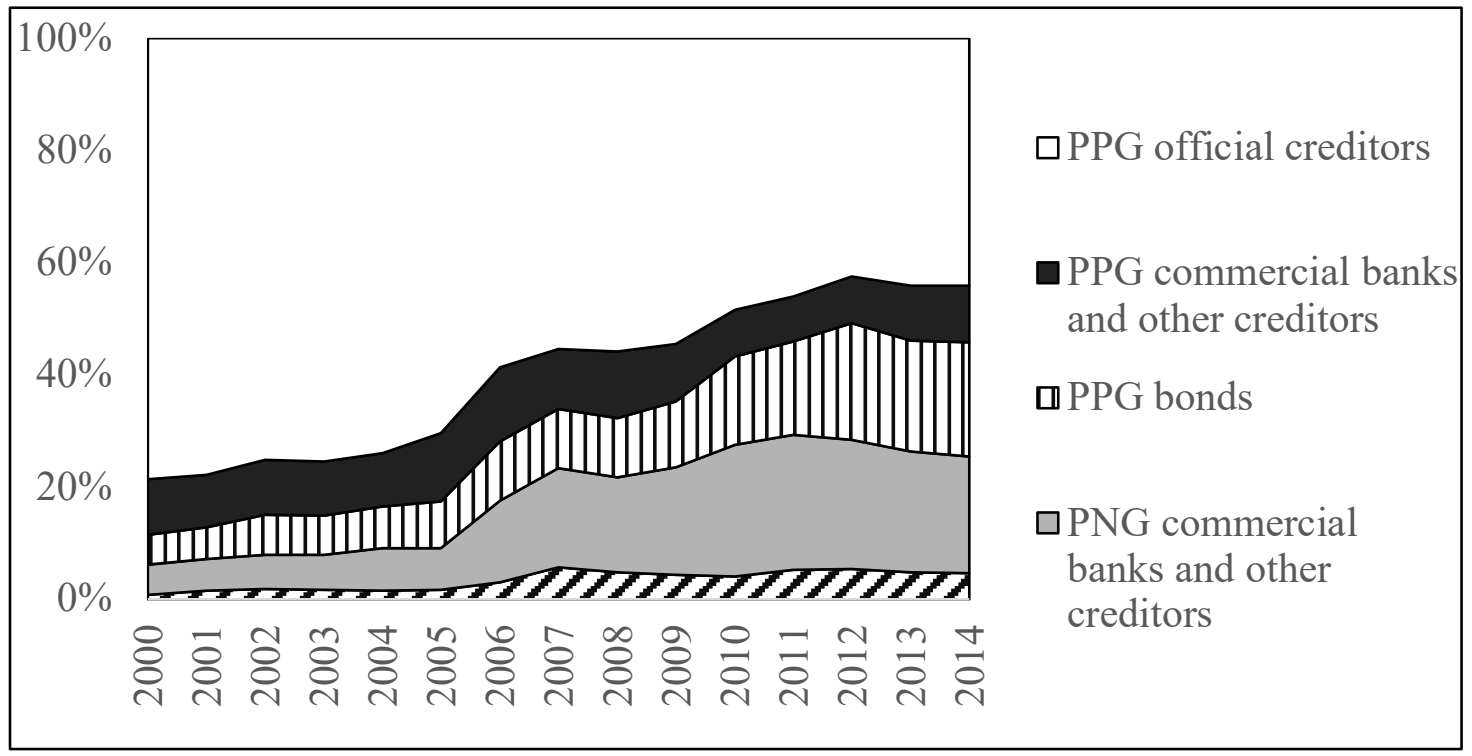

Source: Authors' calculations based on World Bank (2016).

Figure 2. Flows and Holdings of Sub-Saharan African Bonds Funds by Mutual Funds

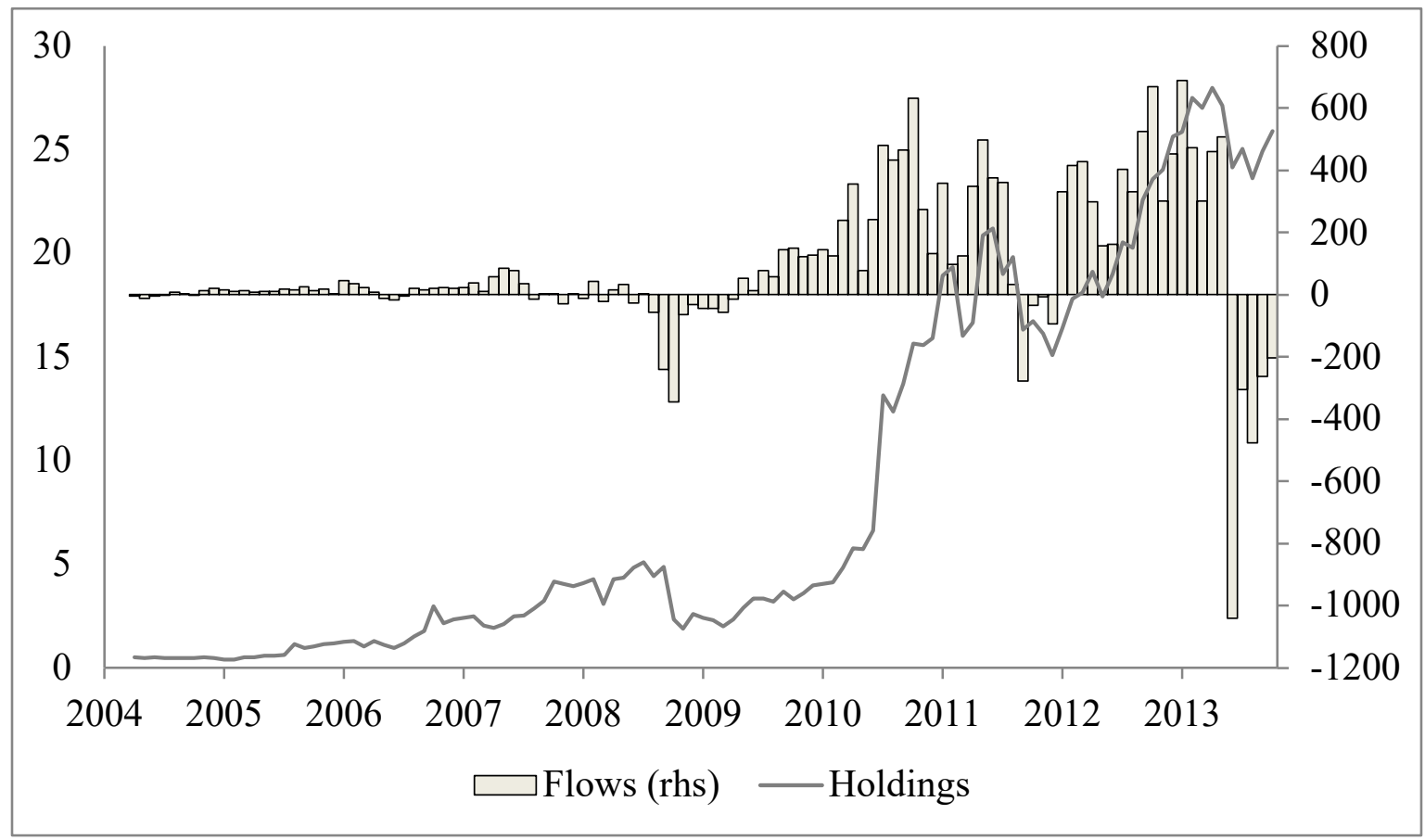

Note: flows (rhs) are in US\$ millions, holdings (lhs) are in US\$ billions 
Source: Authors' calculations based on Emerging Portfolio Research Fund (https://www.epfrglobal.com) Country Flows database.

Figure 3. Incidence of Official Debt in FC and non-FC Countries

\begin{tabular}{|c|c|}
\hline $100 \%$ & $100 \%$ \\
\hline $90 \%$ & $90 \%=$ \\
\hline $80 \%,-\cdots$ & $80 \%$ \\
\hline $70 \%$ & $70 \%$ \\
\hline $60 \%$ & $60 \%$ \\
\hline $50 \%$ & $50 \%$ \\
\hline $40 \%$ & $40 \%$ \\
\hline $30 \%$ & $30 \%$ \\
\hline $20 \%$ & $20 \%$ \\
\hline $10 \%$ & $10 \%$ \\
\hline $0 \%$ & $0 \%$ \\
\hline 200020032006200920122015 & 200020032006200920122015 \\
\hline
\end{tabular}

Note: The black line shows median values, dashed and dotted lines show the interquartile range. FC panel on the left, Non-FC on the right.

Source: Authors' calculations based on World Bank (2016). 
Figure 4. Selected External DSF Indicators

PPG Debt to Exports
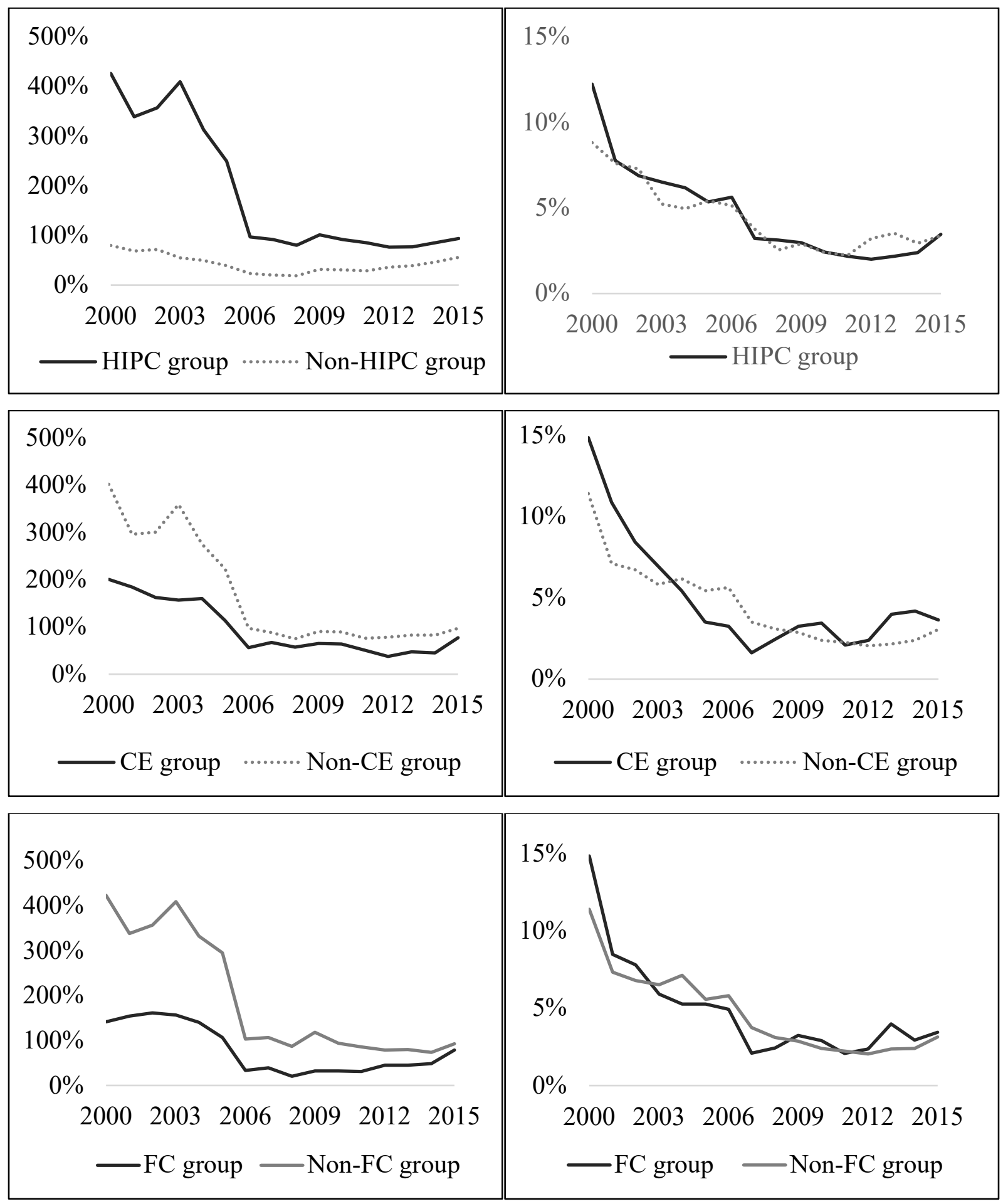

Note: The figures show the median value for each of the country groups. These figures show the 
ratio to exports. Other figures, calculating the other DSF solvency and liquidity ratios, have been calculated and are available from the authors on request.

Source: Authors' elaboration based on the World Bank (2016) and IMF's World Economic

Outlook (IMF, 2016).

Figure 5. Exchange Rates in Selected Countries, 1 January $2005=100$

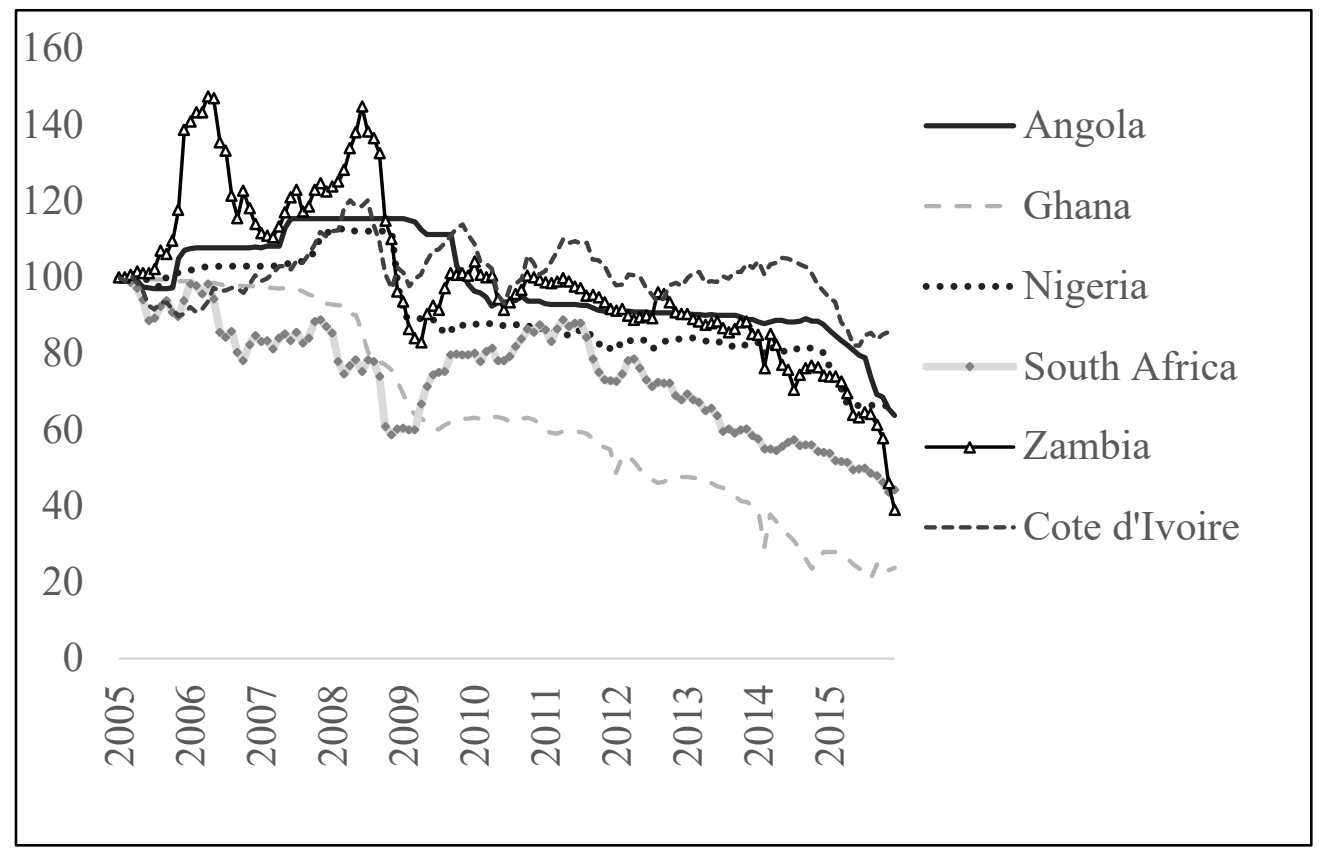

Source: World Bank Global Economic Monitor (https://datacatalog.worldbank.org/dataset/globaleconomic-monitor), exchange rates vis-à-vis US dollar 
Figure 6. Global Liquidity

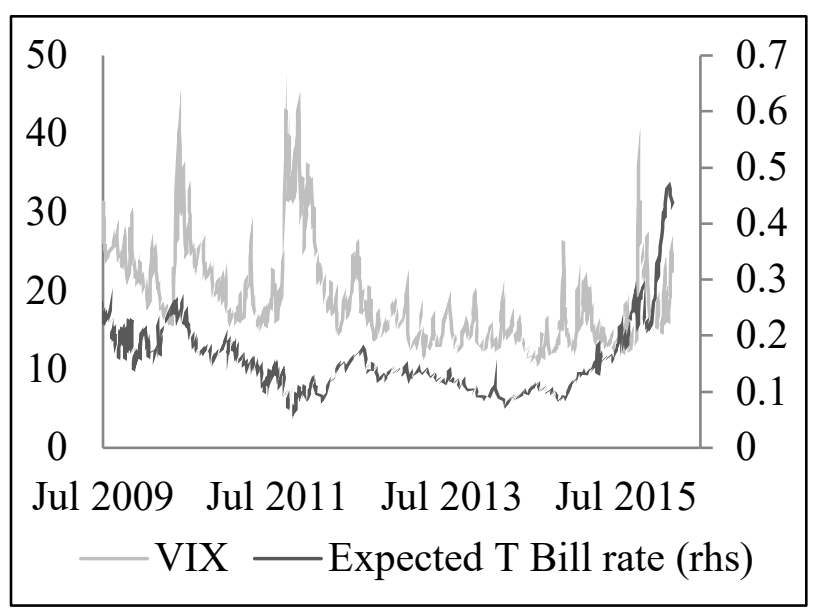

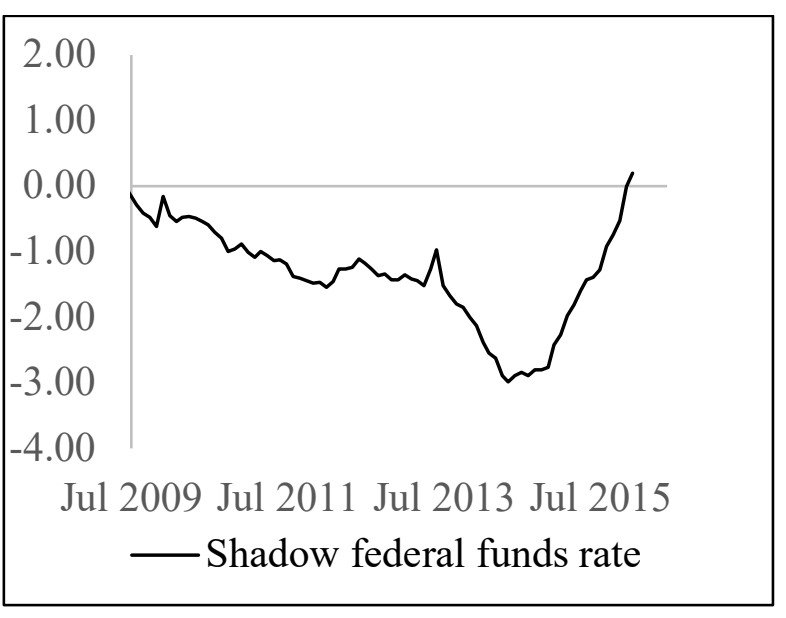

Note: Expected Treasury Bill and $\mathrm{Wu}-\mathrm{Xia}$ shadow rates are expressed in percentage points. Source: Bloomberg (Tickers: S0042FC 3M1D BLC Curncy, VIX); Wu and Xia (2016).

Figure 7. Sovereign Bonds Spreads as a Percentage

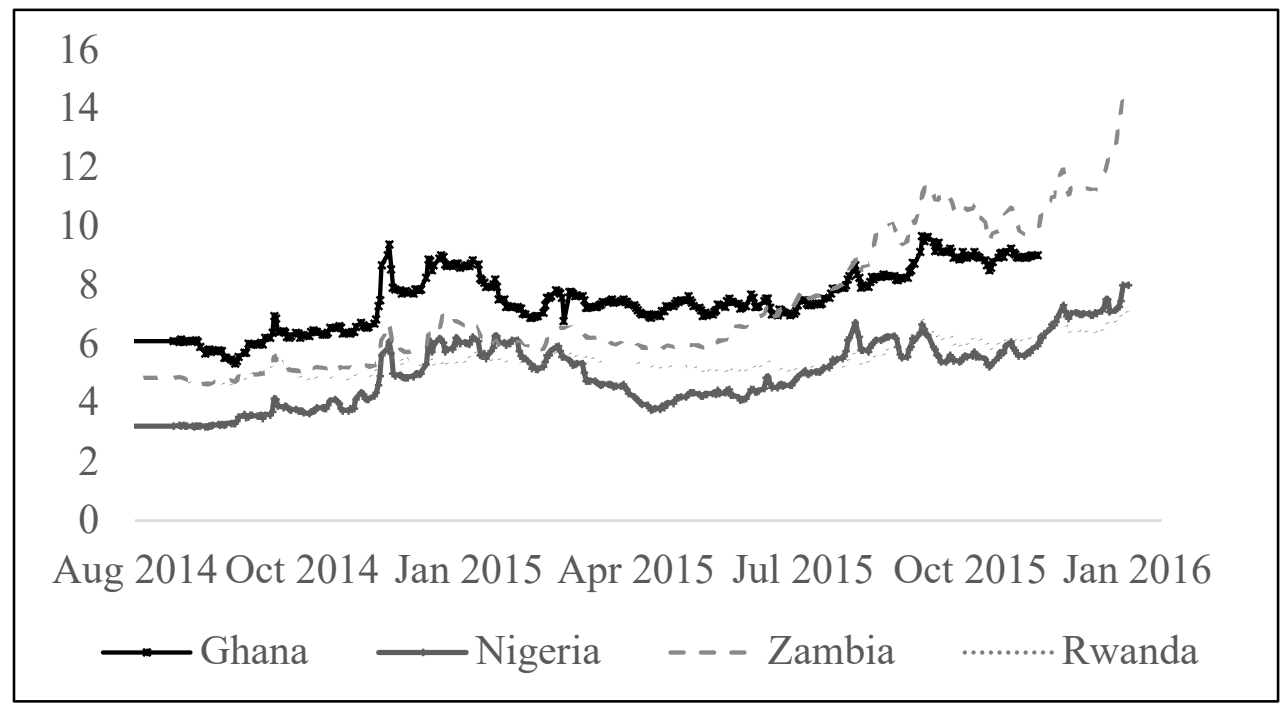

Note: Yield spreads are calculated as the difference between the yields on foreign currency bonds, based on indices for each of the countries, and the yields on Bloomberg bond index for global developed countries debt. These indices are part of Bloomberg's own produced bond indices.

Source: Authors' calculation based on Bloomberg Barclays Indices database (Tickers: BGSV, BEMSGH, BEMSNG, BEMSZM, BEMSRW). 